\title{
The Mythology of Capital in the Twenty-First Century
}

\author{
Vipin P. Veetil ${ }^{*}$ \\ George Mason University
}

\begin{abstract}
In Capital in the Twenty-First Century, Thomas Piketty argues that capitalism can generate arbitrary and unsustainable levels of inequality. He proposes a host of measures to alter the institutions of capitalism to create a more just social order. Piketty's analytical framework, however, assumes away the reasons for the very existence of the institutions he intends to modify. In addition, Piketty treats capital as a homogeneous entity. In the real world, there is no such thing as "capital" apart from the concrete and specific forms it takes. Capital has both a time structure and a goods structure, with varying degrees of specificity within those structures. The price system, along with other institutions, coordinates the capital structure of an economy. Without heterogeneity of capital, there are no coordination problems, and without coordination problems, there is no need for the institutions of capitalism. In this sense, Capital in the Twenty-First Century is prescription without diagnosis.
\end{abstract}

JEL Codes: D33, E22, P16

Keywords: Piketty, inequality, capital structure, coordination, prices

\section{Introduction}

Self-reflection is not a luxury warriors can afford. For much of the twentieth century, capitalism fought fascism, communism, and socialism of all hues. The great wars are over. Ours is the century in which capitalism goes to therapy. Capitalism will look into itself. And when it does, many problems will surface, one of them being inequality. In the United States, income inequality has increased considerably since the 1970s. What are the fundamental causes of inequality in capitalist societies? Will the trend of rising inequality continue? If so, for how long? Will inequalities rise to unsustainable levels? Will capitalism collapse from within? With Capital in the Twenty-

\footnotetext{
* I thank Peter Boettke, James Broughel, Christopher Coyne, Alex Salter, Edward Stringham, Akshaya Vijayalakshmi, and Richard Wagner. All errors are my own.
} 
First Century, Thomas Piketty takes a lead in answering the questions of our age.

Piketty says that inequality in income derived from the ownership of capital is far greater than the inequality in income derived from labor. Therefore, if the share of income that accrues to capital increases, so will inequality. He finds that this share has increased since the Second World War. This empirical fact breaks the hegemony of neoclassical growth models that assume that the share of income that accrues to capital is a technological constant (Solow 1994).

Why has there been an increase in the share of income that accrues to capital? According to Piketty, in the long run, the share depends on the relationship between the rate of return to capital and the rate of growth of output. The greater the rate of return to capital relative to the rate of growth of output, the higher the long-run share of income that accrues to capital. For some parameter values, the share is greater than one. This would make the dynamics of capitalism unsustainable, ultimately leading to its collapse. Piketty offers a bouquet of policy measures to avoid such a collapse.

The problem is that Piketty views capital as a self-perpetuating homogeneous entity that begets itself. In the real world, there is no such thing as capital apart from its concrete and specific manifestations. There are tables, computers, pens, jet engines, and tractors. The web of relationships between the different kinds of capital goods embodies the web of relationships between the intertemporal production plans of different economic agents. The price system and other institutions of capitalist economies are means of coordinating their capital structures (Mises 1949). Piketty studies a world in which the problem of coordinating the structure of capital does not exist because capital is homogeneous. Insofar as Piketty's policy prescriptions intend to alter the institutions of capitalism, their effects and costs cannot be understood by studying a world in which these institutions have no role.

Furthermore, Piketty does not provide a theory of inequality. He argues that inequality depends on the relationship between the rate of return to capital, the rate of saving, and the rate of economic growth. Variables like the rate of return to capital and inequality do not act on each other (Wagner 2010). Individuals make plans and engage in economic actions (Mises 1960). Aggregate variables like inequality are the emergent outcomes of the interactions between purposeful economic actors (Epstein 2006). Aggregate variables do not have a 
life of their own (Schumpeter 1939, pp. 43-44); they are not the primitives of economic analysis, they are the derivatives of individuals' choices. Piketty does not tell us how microeconomic interactions between economic actors generate macroeconomic inequality.

The paper is organized as follows. Section 2 summarizes what Piketty calls the fundamental laws of capitalism. Section 3 defines the structure of capital. Section 4 explains how the structure of capital in an economy is an emergent outcome of the interactions between many human beings, each pursuing her own ends. Section 5 offers concluding remarks.

\section{The Fundamental Laws of Capitalism à la Piketty}

Neoclassical growth models presume that the question of how total income is divided between labor and capital is settled by a technological constant. Consider the Solow (1956) and Swan (1956) growth model with a Cobb-Douglas production function: $Y=K^{\swarrow} L^{1-}$ ' In the neoclassical model, the shares of output that accrue to capital and labor are $\langle$ and $1-\langle$, respectively. Many economists, including Keynes and Samuelson, have claimed that the ratio is stable (Piketty 2014, p. 220); modern macroeconomics textbooks echo this view (Romer 2006). Piketty (2014, p. 218) breaks this "peaceful and harmonious view of the social order." He finds that since the 1970 s, the share of income accruing to capital has increased in all countries for which data are available.

What explains the increase in the share of output accruing to capital? Piketty presents a mechanical explanation based on two factors. One, since the Second World War, there has been a steady increase in the quantity of capital. Two, the increase in the quantity of capital has led to a less than proportional fall in the price of capital. The two factors together have meant that the share of income accruing to capital has been on the rise.

The share of output that accrues to capital is important because income from capital is more unequally distributed than income from labor. This is true for all countries for which data are available. While those in the bottom half of the wage distribution receive 25 percent to 33 percent of total labor income, those in bottom half of the wealth distribution receive less than 5 percent of total capital income (Piketty 2014, p. 244). This means that an increase in the share of output accruing to capital is associated with an increase in inequality — which is why Piketty's book is titled Capital in the TwentyFirst Century (emphasis mine). 
In the neoclassical world, inequality is not a problem. Even if it were, human beings can do nothing about it. After all, the split between labor and capital is a technological parameter, not a political parameter. In Piketty's world, there is a problem: the share of income accruing to capital has been increasing, and so has inequality. Furthermore, the distribution of income can be modified through political means.

Piketty claims that capitalism does not have a self-corrective mechanism to prevent the increase in the share of income that accrues to capital. In fact, there are reasons to believe that the rising inequality is a reflection of the internal contradictions of capitalism. According to Piketty, the long-run share of capital in income depends on the relationship between the rate of saving, the interest rate, and the growth rate. In particular, the long-run share of capital in income is given by the following equation: $\langle=s r / g$, where $\langle$ is the share of capital in income, $s$ is the rate of saving, and $g$ is the rate of growth of output. For a given rate of saving, the share of income that accrues to capital depends on the relationship between interest rate and growth rate. Herein lies the fundamental force of divergence between the share of capital and the share of labor in income. If the rate of saving is 20 percent, the rate of return on capital 10 percent, and the rate of output growth 4 percent, then capital's share in income will asymptotically tend toward 50 percent. If the rate of growth of output declines to 2 percent, then capital's share in income will tend toward 100 percent. And if the rate of growth of output declines below 2 percent, then the share of capital in income will tend toward more than 100 percent, which is unsustainable. For some parameter values, the dynamics of a capitalist economy lead to undesirable outcomes; for other parameter values, those dynamics lead to altogether unsustainable outcomes. Marx's world is a subset of Piketty's world, a parametric realization.

Piketty says that Marx was led to believe that capitalism will necessarily collapse because he assumed that the rate of growth of output will be near zero. In such a world, the share of income that accrues to capital will tend to a value greater than one for nearly any rate of saving and rate of return to capital. This mathematical impossibility is a reflection of the internal contradictions of capitalism. As labor's share of income declines, workers organize and revolt. Workers revolt not because of their concern for inequality or for Marx, but because the increase in < ultimately causes a decline in 
their absolute income, driving it toward zero. Capitalism contains the seeds of its own destruction.

According to Piketty (2014, p. 10), the rate of growth of output counterbalances the rise in inequality, which is a possibility that "Marx totally neglected." The question of whether capitalism will collapse if left to its own devices becomes an empirical question, which Piketty answers in the affirmative. Piketty (2014, p. 353) finds that for much of human history, the rate of return to capital has been 10 to 20 times greater than the rate of growth of output. This means that a rate of saving of greater than 10 percent would make the share of capital in output tend to greater than one: an impossibility. The fundamental cause of income inequality in capitalism has nothing to do with any market imperfection. Quite the contrary: "the more perfect the capital market (in the economists' sense), the more likely $r$ [the rate of return to capital] is to be greater than $g$ [the rate of growth of output]" (Piketty 2014, p. 27).

Though Piketty is Marx in diagnosis (without the materialistic conception of history), he is Keynes in prescription. The collapse of capitalism is not a historical law but an empirical possibility-a possibility that can be altered with a bouquet of policy measures that Piketty suggests in part four of his book. These include a global tax on capital, more government investment in training workers, and greater dissemination of knowledge. And like the General Theory of Employment, Interest, and Money, Piketty's Capital tells us that much is amiss but all can be fixed. Like the proverbial therapist, Piketty asks us to dig into our childhood and then says, "You're doing just finewell, almost."

\section{The Structure of Capital}

What is capital? Piketty (2014, p. 46) defines it as "the sum of nonhuman assets that can be owned and exchanged on some market." Capital "includes all forms of real property (including residential real estate) as well as financial and professional capital (plants, infrastructure, machinery, patents, and so on) used by firms and government agencies." When Piketty uses the word "capital," what he means is the sum of the values generated by many different kinds of capital.

In the real world, capital exists in concrete forms (Hayek 1936). There are tables, chairs, jet engines, screwdrivers, hammers, surgical equipment, and computers. The different kinds of capital relate to each other in different ways to produce goods. For instance, tables, 
chairs, and computers may be used together to produce software. We shall call the nexus of relationships between different kinds of capital the "capital structure" (Lachman 1956). Capital structure has two dimensions: time structure and goods structure. The time structure of capital is how different kinds of capital relate to each other with respect to the time it takes for their services to become consumer goods. Suppose consumers use electricity to light their homes. The services of a bulldozer used in mining coal take more time to transform into light than the services of the generator that uses coal to produce electricity. In the production of light, the bulldozer is a higher-order type of capital than the electric generator. In an economy with more than one consumer good, it generally will not be possible to rank different kinds of capital with respect to the time it takes for their services to become consumer goods. Suppose consumers use coal for heating their homes. Further assume that electricity is used to produce the bulldozer that extracts coal. The bulldozer is a lower-order type of capital than the electric generator in the production of heating, though it is a higher-order type of capital in the production of lighting. The time structure of capital is not a complete ordering of different kinds of capital; it is a nexus of relationships. It is a reflection of the directions in which services of different kinds of capital flow as time moves forward.

The goods structure of capital is how different kinds of capital are related to each other with respect to the consumer goods they produce. In this relationship, capital goods may be substitutes or complements. Farms that produce apples and farms that produce oranges are substitutes if apples and oranges are substitutes. The two farms are complements if apples and oranges are complements. If a given kind of capital can produce multiple goods, then it may be both a substitute and a complement to another kind of capital.

Finally, capital goods have different degrees of specificity within the time structure and the goods structure. The specificity of capital is the cost of converting one kind of capital into another kind of capital. The lower the cost of converting one kind of capital into another kind of capital, the less specific the capital. The conversion of one into another does not necessarily entail a physical transformation; it merely means that one is used to produce the services of another. In general, it will not be possible to rank the different kinds of capital in an economy with respect to their specificity. Consider the following example. Suppose it is less costly to convert fallow land into an orange orchard than to convert an 
apple orchard into an orange orchard. We can say that fallow land is less specific than an apple orchard with respect to an orange orchard. However, fallow land may be more specific than an apple orchard with respect to a banana plantation. It may be more costly to convert fallow land into a banana plantation than to convert an apple orchard into a banana plantation. The specificity of capital has to do with the network of relationships between different kinds of capital.

The capital structure of an economy is a nexus of relationships with a time structure and a goods structure and different degrees of specificity within those structures. None of these structures is reducible to scalar quantities. Their economic function resides precisely in the network of relationships between different kinds of capital (Lachman 1956, p. 4). The structure of capital in an economy has economic meaning only in terms of the subjective valuations of individuals in an economy. Objective measures of capital, independent of the plans of economic actors, are meaningless. Nothing has caused more difficulty in the theory of capital than the attempts to define a magnitude of capital independent of the subjective valuations of economic actors. These attempts include average period of production (Hayek 1941; Machlup 1935), roundaboutness of production, capital intensity of production (Kaldor 1939), average specificity of capital, and arguments about the lengthening and shortening of the time structure of capital (Garrison 2002). What matters for economic analysis are the concrete forms of capital and structure of the relationships between them. These relationships are the manifestations of the plans of economic actors.

Piketty reduces the capital structure of an economy to a selfperpetuating homogeneous entity called "capital." He follows a long tradition, whose most illustrious proponent in the twentieth century was Frank Knight (Boettke and Vaughn 2002). Knight (1941, p. 418) thought "the entire productive capacity of the economy is a selfperpetuating organic whole or unit." For Knight (1941, p. 421), questions about the emergence and maintenance of capital did not make sense because "capital is inherently self-perpetuating."

The structure of capital in an economy emerges out of the interaction between millions of economic actors pursuing their own ends. No economic actor has global knowledge about how the different kinds of capital fit together. Each owns and alters bits of capital using local knowledge. Prices, profit and loss, the stock market, firms, and social norms are all mechanisms through which economic actors coordinate their plans. It is precisely when these 
institutions function well that the capital structure of an economy behaves as if it were a self-perpetuating homogeneous entity (Kirzner 2010, p. 43). Order creates an illusion of unity, much like how a synchronized flock of birds seems like a single organism. How well these institutions coordinate the plans of different economic actors to bring some semblance of unity in the capital structure depends on the policy environment.

\section{Human Action in a World with Heterogeneous Capital}

What determines the structure of capital? In a Crusoe economy, the time structure and goods structure of capital will depend on Crusoe's time preference and goods preference. The specificity of capital goods will depend on Crusoe's risk preference. Crusoe has all the knowledge necessary to create a capital structure that reflects his preference ordering and the available technology.

In an economy with specialization and exchange, each actor faces Crusoe's problem. But in addition, each actor must find ways to coordinate her plans with those of others (Veetil and Wagner 2015). Insofar as firms borrow loanable funds, the time structure of capital they create must reflect the time preference of savers and the specificity of capital must reflect the risk preference of savers. The goods structure of capital must reflect the goods preference of consumers. Furthermore, the different kinds of capital owned by different firms must be coordinated in a technical sense because one firm's output will often be another firm's input. ${ }^{1}$

Coordination problems arise because of endogenous factors like innovation (Schumpeter 1934) and exogenous factors like weather shocks. Innovation creates differences in expectations and forecasts between those acting within the system. The advent of the automobile destroyed not just the stagecoach industry but also the industries that produced inputs for the stagecoach industry. In such circumstances, economic actors have to transform capital that was of great value yesterday but is of little value today. They must find alternative ways to employ the existing stock of capital. Often, this will involve breaking down capital equipment into parts that may be used in other production processes. For instance, the leather in a stagecoach may be used to make seats in cars, the wood may be used to make tables, and so on. The reallocation of capital in response to

\footnotetext{
${ }^{1}$ See Kelly, Lustig, and Van Nieuwerburgh (2013), Golo et. al (2015), and Luo and Whitney (2015) for data on input-output linkages between firms.
} 
innovation depends on the specific forms in which capital exists and the new forms into which they must be transformed. Heterogeneity matters.

In a capitalist economy, the problem of creating, maintaining, and altering the structure of capital is perennial. In performing these functions, economic actors must be able to forecast the plans of others. Should a baker buy a larger or smaller oven to replace an existing one? In part, the decision depends on the future price of flour, which itself depends on the productivity of flour mills and farms. The price of flour may fall if farmers employ more efficient tractors or if flour mills use a more efficient grinders. A baker's decision on capital maintenance depends on farmers' and flour mill owners' decisions. Different kinds of capital are related to each other through the relationship between the plans of economic actors who use them.

Crusoe is able to coordinate the capital structure of his economy because he has knowledge of preferences and technological possibilities. In a real economy, knowledge of economic significance is not given to a single mind (Hayek 1945; Lavoie and Prychitko 1995; Axtell 2003). Rather, coordination happens through the price system. Suppose an oil field is discovered in the Arctic. Ceteris paribus, it makes economic sense to use more oil and less of oil substitutes. For this to happen, the capital structure of the world economy has to change. Machines that use nonoil fuels must be substituted with machines that use oil. This substitution can be done in variety of ways. Some machines may be broken down or altogether discarded. Others may be modified. Still others may not have to be changed at all. Economic actors who produce, own, or use these machines may not know about the discovery of oil in the Arctic. Nor do they need to know. The discovery of the oil field will cause a fall in the price of oil. This change in price conveys both the knowledge and the incentive necessary for economic actors to change the structure of capital. In response to the price change, some agents will make investments to build oil-using equipment. Others will transform machinery that runs on nonoil fuels to machinery that runs on oil. A change in the price of oil begins a whole sequence of changes in the structure of capital. The functioning of a market economy generates the prices that are necessary for economic actors to engage in calculations that bring about coordination (Mises 1951).

For Knight, the problem of maintenance of capital was one of devoting some portion of output to investment (Kirzner 2010). 
Questions about what investments to make and what factors to consider while making those investments do not arise in a world where capital is homogeneous. In a world where capital is homogeneous, individual choices are of no great importance because the only choice to be made is with regard to the rate of saving. To view an economy as a single production function that transforms a homogeneous stock of capital into output assumes away a wide variety of economic problems. Such a world needs neither prices nor a system of profit and loss.

How well does the price system coordinate the structure of capital - and at what cost? The discovery of relative prices is no easy task. Relative prices are discovered through interactions between economic actors (Smith 1962; Hayek 1968; Kirzner 1997; Axtell 2005; Veetil 2015). Institutions like stock exchanges are means to discover relative prices of different kinds and bundles of capital. These mechanisms are costly both when they get prices right and (even more so) when they get prices wrong.

In much of neoclassical economics, prices play the role of parameters. They are computed by a Walrasian auctioneer in metatime and at zero cost. Furthermore, in the neoclassical world, prices are always correct; no trade is allowed at disequilibrium prices (Weintraub 1993). In such a world, human action is mechanical (Boettke and Veetil forthcoming); no interpretation of prices is necessary. In the real world, interpretation is necessary (Boettke 1990; Lavoie 1994). The price system is the lighthouse of the economic system. It does not direct economic activity, but it serves as a useful guide to economic decision making. Prices are not sufficient statistics - they are useful statistics. They must be interpreted with the use of nonprice information, which is often local.

There are two reasons why prices tend not to be sufficient to make economic decisions. One, prices contain noise for a variety of reasons, including mistakes by traders. Plausibly, there is less noise in the price of assets that are traded more often and by more individuals. Nonetheless, noise cannot be eliminated. Economic actors must find ways to distill signal from noise.

Two, price changes are not synchronous. There is a delay between the time at which economic changes happen and the times at which they are reflected into prices. This is because decentralized interactions are necessary to generate new prices. The delay need not be equal for all goods and all sectors of the economy. Insofar as some changes get reflected in prices sooner than others, the 
prevailing prices have different time stamps. Much like light from distant galaxies, different prices come from different times. The delay in price formation means that prevailing prices do not reflect the prevailing state of the world. The differences in delay mean that they do not reflect a particular past state of the world. Economic actors must decipher and interpret these price signals to forecast, however well or poorly, what the future world will look like for them.

In fact, the problem of interpreting prices to make economic decisions is so difficult and significant that some economic actors specialize in this function. Institutions like stock exchanges are systems of interactions through which these actors form and interpret prices. There is no general formula for successful interpretation. Rather, strategies that succeed survive and those that fail are eliminated (Alchian 1950; Axelrod 1987). Rules for creation and interpretation of prices evolve as the economic process unfolds (Lachman 1956, p. 10).

Yet, the evolutionary process is not wholly unstructured. Significant elements of knowledge are embedded in the form of institutions (Potts 2001; Foss and Garzarelli 2007; Coyne and Veetil 2015). The New York Stock Exchange and the Chicago Mercantile Exchange have different rules of interaction. These rules of interaction are embedded knowledge about how to form and interpret prices for different kinds of capital. These institutions will tend to collapse and be replaced by new ones when economic circumstances make the knowledge they contain obsolete and misleading.

The fact that economic actors have to interpret prices explains why income distribution cannot be explained by objective criteria. It is no surprise, then, that Piketty does not find objective factors that correlate with the distribution of income. He writes,

This very sharp discontinuity at the top income level is a problem for the theory of marginal productivity: when we look at the changes in the skill levels of different groups in income distribution, it is hard to see any discontinuity between the "the 9 percent" and "the 1 percent," regardless of what criteria we use: years of education, selectivity of educational institution, or professional experience. One would expect a theory based on "objective" measures of skill and productivity to show relatively uniform pay increases within the top decile, or at any rate increases within different subgroups much closer to one another than the widely 
divergent increases we observe in practice. (Piketty 2014, p. 314)

Lachmann (1956, p. 22) thought that in "a market economy success depends largely on the degree of refinement of one's instruments of interpretation." In a world where economic actors are rewarded for interpreting prices, there need not be any relationship between the objective measurable skills possessed by individuals and the incomes they earn. The ability of an individual to interpret prices may have little to do with her level of education, work experience, and other measurable characteristics. Piketty takes us back to the dark days of the labor theory of value by seeking an objective explanation for income inequality.

\section{Concluding Remarks}

Piketty (2014, p. 31) is "interested in contributing, however modestly, to the debate about the best way to organize society and the most appropriate institutions and policies to achieve a just social order." These institutions include the price system, stock exchanges, profit and loss accounting, and private property. Though Piketty intends to alter these institutions, his analytical framework assumes away the very purpose of their existence. The presumption that capital is a homogeneous self-perpetuating entity means that neither property nor prices are necessary for coordinating the structure of capital. Piketty presumes that his policies will not dampen the process through which the structure of capital is created and maintained. To repurpose a sentence Mises (1949, p. 848) used to critique welfare economics, Piketty "fails to comprehend that even the mere maintenance of capital depends on the skillful handling of the problems of investment, that it is always the fruit of successful speculation, and that the endeavor to maintain capital intact presupposed economic calculation and thereby the operation of the market economy." Policymakers ought to be wary of Piketty's recommendations. A policymaker who assumes that capital is a selfperpetuating homogeneous entity is akin to a helmsman who assumes that his ship will stay afloat. Piketty falls prey to the Ricardian vice (Schumpeter 1954).

Piketty (2014, p. 215) asks whether "it is useful and just for owners of capital to receive its marginal product as payment for their ownership of property (whether their own past savings or that of their ancestors) even if they contribute no work?" In a world where capital is homogenous, the answer to such a question is obvious. But 
in a world where capital is heterogeneous, no one is rewarded for merely owning "capital." Rather, individuals are rewarded for owning and maintaining particular kinds of capital (Holcombe 2015). Furthermore, they are rewarded only insofar as the capital they own is useful to others and coordinated with the capital owned by others. Those who own featherweight steamrollers earn no returns. Nor do those who produce jet engines that do not fit into aircrafts.

This is not to suggest that the rewards that a market economy bestows upon owners of capital are "just." After all, the market economy is no god, king, or economist. The market is a process of interactions between purposefully behaving economic actors. The market does not have a teleology of its own (Buchanan and Vanberg 1991). The distribution of wealth is an emergent property of the system. There is no reason to presume that the process will generate distributions that appeal to the subjective valuations of moral philosophers.

Piketty (2014, p. 440) lambasts Liliane Bettencourt, "who never worked a day in her life" but "saw her fortune grow exactly as fast as that of Bill Gates." Bettencourt is the daughter of Eugene Schueller, the founder of L'Oreal. Presumably, she enjoys the fortunes created by her father. The market economy rewarded Schueller quite handsomely, with enough money not only for himself, but for his child, too. Was the reward too much? Was it too little? These are questions that a value-free science cannot answer.

However, the cost interventions to "correct" market rewards cannot be understood without a recognition of the purpose of these rewards. Schueller was not rewarded for owing capital; rather, he was rewarded for creating particular kinds of capital to satisfy particular consumer needs, given the existing structure of capital. Would he have created L'Oreal had he known that he would not be allowed to leave bequests for his daughter? What if he were allowed to bequest only half of his property? These are difficult questions. But Piketty makes no attempts to answer them.

The capitalist economy lives in the perennial gale of creative destruction (Schumpeter 1942). No equipment, however productive, will yield returns forever. The greater the gales of creative destruction, the shorter the expected lifespan of capital. Creative destruction is a bottom-up force of redistribution. How much wealth is redistributed by creative destruction? And how does this redistribution affect income inequality? These are empirical questions. Nonetheless, back-of-the-envelope calculations suggest that the total 
amount of wealth redistributed by the New York Stock Exchange dwarfs all government programs put together. Its market capitalization is nearly equal to the GDP of the United States. Daily movements in different stocks redistribute vast amounts of wealth. Those who succeed in forecasting the future gain wealth, and those who fail lose wealth. Insofar as one's ability to forecast the economic future does not depend solely on the quantity of wealth one owns, these redistributions reduce the share of income that goes to owners of existing kinds of capital. Government interventions that dampen the gales of creative destruction favor owners of the existing stock of capital over those who do not own capital. To the extent that the policies Piketty recommends are likely to dampen the gales of creative destruction, in theory, the impact of these policies on income inequality is ambivalent.

The bottom-up process of creative destruction is more incentive compatible than the state-led redistribution Piketty proposes. If, indeed, capitalism is on the path of ever-increasing inequality, then it is also on a path of ever-increasing power in the hands of those who own wealth. It remains unclear what incentives would propel the state to confiscate wealth from those who are powerful. The state and the market economy are entangled systems (Wagner 2013). Forces that change the distribution of wealth in the market will be reflected in the behavior of the state. Piketty takes the behavior of the state to be not only exogenous to the functioning of the market economy but also malleable to the dictates of economists, a matter on which both Marx and Pareto would have disagreed with him.

\section{References}

Alchian, Armen A. 1950. "Uncertainty, Evolution, and Economic theory." Journal of Political Economy, 58(3): 211-21.

Axelrod, Robert. 1987. "The Evolution of Strategies in the Iterated Prisoner's Dilemma." The Dynamics of Norms, ed. Christina Bicchieri, Richard Jeffrey, and Brian Skyrms, 1-16. Cambridge: Cambridge University Press.

Axtell, Robert L. 2003. "Economics As Distributed Computation." In Meeting the Challenge of Social Problems via Agent-Based Simulation, ed. Hiroshi Deguchi, K. Takadama, and Takao Terano, 3-23. Tokyo: Springer.

Axtell, Robert L. 2005. "The Complexity of Exchange." Economic Journal, 115(504): F193-F210.

Boettke, Peter J. 1990. "Interpretive Reasoning and the Study of Social Life." Methodus: Bulletin of the International Network for Economic Method, 2(2): 35-45.

Boettke, Peter J., and Karen Iversen Vaughn. 2002. "Knight and the Austrians on Capital, and the Problem of Socialism." History of Political Economy, 34(1): 15576. 
Boettke, Peter J., and Vipin P. Veetil. Forthcoming. "Models of Human Action. Cosmos + Taxis.

Buchanan, James M., and Viktor J. Vanberg. 1991. "The Market As a Creative Process." Economics and Philosophy, 7(2): 167-86.

Coyne, Christopher J., and Vipin P. Veetil. 2015. "Learning As an Emergent, Creative Process." Review of Austrian Economics.

Epstein, Joshua M. 2006. Generative Social Science: Studies in Agent-Based Computational Modeling. New Haven: Princeton University Press.

Foss, Nicolai J., and Giampaolo Garzarelli. 2007. "Institutions As Knowledge Capital: Ludwig M. Lachmann's Interpretative Institutionalism.” Cambridge Journal of Economics, 31(5): 789-804.

Garrison, Roger W. 2002. Time and Money: The Macroeconomics of Capital Structure. New York: Routledge.

Golo, Natasa, Guy Kelman, David S. Bree, Leanne Usher, Marco Lamieri, and Sorin Solomon. 2015. "Many-to-One Contagion of Economic Growth Rate across Trade Credit Network of Firms." Cornell University Library.

Hayek, Friedrich A. 1936. "The Mythology of Capital." Quarterly Journal of Economics, 50(2): 199-228.

Hayek, Friedrich A. 1941. The Pure Theory of Capital. London: Macmillan and Co.

Hayek, Friedrich A. 1945. "The Use of Knowledge in Society." American Economic Review, 35(4): 519-30.

Hayek, Friedrich A. 1968. "Competition As a Discovery Procedure." Translated by Marcellus S. Snow. Quarterly Journal of Austrian Economics (2002), 5(3): 9-23.

Holcombe, Randall G. 2015. "Capital and Labor, Past and Present, in the Context of Piketty's Capital." Review of Austrian Economics, 28(2): 195-207.

Kaldor, Nicholas. 1939. "Capital Intensity and the Trade Cycle." Economica, 6(21): 40-66.

Kelly, Bryan, Hanno Lustig, and Stijn Van Nieuwerburgh. 2013. "Firm Volatility in Granular Networks." National Bureau of Economic Research Working Paper 19466.

Kirzner, Israel M. 1997. "Entrepreneurial Discovery and the Competitive Market Process: An Austrian Approach.” Journal of Economic Literature, 35(1): 60-85.

Kirzner, Israel M. 2010. Essays on Capital and Interest. Indianapolis: Liberty Fund.

Knight, Frank H. 1941. "Professor Mises and the Theory of Capital." Economica, 8(32): 409-27.

Lachmann, Ludwig M. 1956. Capital and Its Structure. London: Bell \& Sons Ltd.

Lavoie, Don. 1994. "The Interpretive Turn." The Elgar Companion to Austrian Economics, ed. Peter J. Boettke, 54-62. Northampton, MA: Edward Elgar.

Lavoie, Don, and D. Prychitko. 1995. "The Market As a Procedure for the Discovery and Conveyance of Inarticulate Knowledge." F. A. Hayek: A Critical Assessment, ed. John C. Wood and Ronald N. Wood, 115-37. London: Routledge.

Luo, Jianxi, and Daniel E. Whitney. 2015. "Asymmetry in In-Degree and OutDegree Distributions of Large-Scale Industrial Networks." Cornell University Library.

Machlup, Fritz. 1935. "Professor Knight and the Period of Production." Journal of Political Economy, 43(5): 577-624.

Mises, Ludwig. 1949. Human Action. New Haven: Yale University Press. 
Mises, Ludwig. 1951. Socialism: An Economic and Sociological Analysis. New Haven: Yale University Press.

Mises, Ludwig. 1960. Epistemological Problems of Economics. New York: D. Van Nostrand Co.

Piketty, Thomas. 2014. Capital in the Twenty-First Century. Boston: Harvard University Press.

Potts, Jason. 2001. "Knowledge and Markets." Journal of Evolutionary Economics, 11(4): 413-31.

Romer, David. 2006. Advanced Macroeconomics. New York: McGraw-Hill.

Schumpeter, Joseph A. 1934. The Theory of Economic Development: An Inquiry into Profits, Capital, Credit, Interest, and the Business Cycle. Cambridge, MA: Harvard University Press.

Schumpeter, Joseph A. 1939. Business Cycles. New York: McGraw-Hill.

Schumpeter, Joseph A. 1942. Capitalism, Socialism and Democracy. New York: Harper and Brothers.

Schumpeter, Joseph A. 1954. History of Economic Analysis. Oxford: Oxford University Press.

Smith, Vernon L. 1962. "An Experimental Study of Competitive Market Behavior." Journal of Political Economy 70(2): 111-37.

Solow, Robert M. 1956. "A Contribution to the Theory of Economic Growth." Quarterly Journal of Economics, 70(1): 65-94.

Solow, Robert M. 1994. "Perspectives on Growth Theory." Journal of Economic Perspectives, 8(1): 45-54.

Swan, Trevor W. 1956. "Economic Growth and Capital Accumulation." Economic Record, 32: 334-61.

Veetil, Vipin P. 2015. "Out-of-Equilibrium Dynamics with Heterogeneous Capital Goods." Mimeo.

Veetil, Vipin P., and Richard E. Wagner. 2015. "Treating Macro Theory As Systems Theory: How Might It Matter?" In New Thinking in Austrian Political Economy, 119-43. Emerald Group Publishing Limited.

Wagner, Richard E. 2010. Mind, Society, and Human Action: Time and Knowledge in a Theory of Social-Economy. New York: Routledge.

Wagner, Richard E. 2014. "Entangled Political Economy: A Keynote Address." Advances in Austrian Economics. Emerald Insight.

Weintraub, E. Roy. 1993. General Equilibrium Analysis: Studies in Appraisal. Cambridge: Cambridge University Press. 